\title{
15. Exile as Transformation and a Will to Meaning: Viktor Frankl, Simon Wiesenthal
}

For a few outstanding writers, scholars, and individuals, exile turns into a personal transformation. A scholarly way of addressing the extreme inhumanity of the world is found in the work of the Viennese psychologist Viktor Frankl (b. 1905 in Vienna, d. 1997 in Vienna). His book Man's Search for Meaning (1946) has become a bestseller due to its response to the postwar generation's need to come to terms with a world forever changed.

Frankl chose to stay with his parents in Vienna, even though he had a visa to escape to the US, and thus went through the frightening experiences of Theresienstadt, Auschwitz, and Dachau, where most of his family died. The only survivor was his sister Stella, who emigrated to Australia after the war.

Unlike Freud, Frankl came to the conclusion that neurosis arises from the individual's failure to find meaning and a sense of responsibility for their existence, rather than a question of sexual instincts and repressions. He was the founder of the Third Viennese School of Psychotherapy. The Second School was formed by Alfred Adler (b. in Vienna in 1870, d. 1937 in Aberdeen, Scotland), a Viennese Jew who had to close his clinics (even though he converted to Catholicism) and emigrate to the US in the 1930s.

Adler was concerned with overcoming the superiorityinferiority dynamic and was one of the first psychotherapists to discard the analytic couch in favor of two chairs. The latter allows the clinician and patient to sit together more or less as equals. He was also an early feminist and holistic psychologist. Clinically, Adler's methods are not limited to treatment after-the-fact, but extend to the realm of prevention by preempting future problems in 
the child. Prevention strategies include encouraging and promoting social interest and belonging and a cultural shift within families and communities that leads to the eradication of both pampering and neglect. In other words, Adler stresses the social in psychology, unlike Freud.

His influence is vast. Much of Adler's work has been absorbed into modern psychology without attribution. Together with Freud and Jung, he is considered one of the fathers of depth psychology. He influenced the foremost founders of humanistic psychology, like Abraham Maslow, Rollo May, and so on. Instead of Freudian instinctual demands, in Adler's view individuals are fueled according to these figures by goals and an unknown creative force.

Frankl's school, then, is interested in the "will to meaning" which, for him, is more important than the pleasure principle on which Freud's psychoanalysis is founded or the "will to power" in Adlerian psychology. In his famous book Man's Search for Meaning, which is based on his experiences in the concentration camps, Frankl explores the psychological processes experienced by the prisoners. He observes that while all the functions of body and mind deteriorated or were reduced to the lowest common denominator, spiritual life continued. His recommendation for people undergoing extreme suffering is to remain brave, dignified, and unselfish in order to find a meaning and purpose. Further, he argues that dreaming and looking at suffering as if it is already in the past is helpful.

A prisoner who lost faith in the future loses hold of his inner self, Frankl writes. Whereas responsibility for another human being or for unfinished work keeps one alive. The meaning of life is infinite and suffering needs to be borne proudly. Frankl also describes the psychological reaction of prisoners after liberation. Freedom brings its own challenges and needs to be used wisely. People needed to be taught that they were not entitled to do wrong even if wrong had been done to them.

Frankl's "logotherapy" is based on discovering people's deep longings, on understanding love as grasping another human being in the innermost core of their personality, and sex as a vehicle for love. Suffering ceases to be suffering as soon as it finds a meaning. 
It can thus be ennobling or degrading. Life lived to the fullest, even if it is transitory, is a source of satisfaction. Self-transcendence is the ultimate cure, whether through laughter, which causes selfdetachment, or through walking away from obsessions by creating an opposite intention. An individual, Frankl believes, is essentially self-determining and can change at any moment. A person can lose their usefulness but not dignity. Thus, in the context of the Holocaust, Frankl believes that suffering can be turned into a human achievement and thereby transformed. It is the loss of an orientation towards meaning that causes death.

According to Frankl, thirty percent of the current population lacks meaning in life and lives in an existential vacuum - which leads to depression, aggression, and addiction. Yet meaning is available despite suffering and even through it. Value should be measured by dignity rather than usefulness. Love, work, pride in suffering, and personal growth are all sources of meaning. The challenge is to join the decent people in life, who are in a minority.

Frankl found a source of transformation, and his "exile" really leads back to the center of the individual, back to rejoining the human community. Unfortunately, not all of his co-prisoners had a chance or the capacity to do so. Frankl says in one of his studies that the meaning of man's life is connected with "the feeling that he lives for the sake of something or someone else." ${ }^{\prime 65}$ During extreme and prolonged suffering, however, when a person is deprived of this "someone" or "something else, not everyone finds the strength to recreate these absences in their mind." ${ }^{66}$ Frankl cautions that we tend to ascribe an absolute value to relative values. He says that despair has its roots in divinization, in the absolutization of some

V. E. Frankl, "Das Gefühl, . . . für etwas, da zu sein - für etwas oder für jemand ... ," in Psychotherapie für den Layen. Rundfunkvorträge über Seelenheilkunde, vol. 2 (Auflage, Freiburg im Breisgau: Herder, 1971), 50.

66 Peter Tavel, "The Connection between Thomism and the Theory of Viktor E. Frankl on the Meaning and Goal of Life," Angelicum 87, no. 4 (2010): 867. 
single relative value which, though significant, man regards as the only possible meaning of his life.

Frankl became one of the key figures of existential therapy and a prominent source of inspiration for humanistic psychologists. He lived in Vienna and often taught in the US; he received many honorary doctorates and prizes; he wrote thirty-nine books and was translated into forty languages. One of his great contributions also consists in stressing that freedom is only half of the story. The other half is responsibility.

Timothy Pytell, who offers an extensive historical background on Frankl's life and work, claims that Frankl actually spent only a few days in Auschwitz and yet "portrayed the Holocaust as a 'manageable' experience that (with luck) was survivable, but his version clashed with what we know about the 'reality' of Holocaust experience." ${ }^{\prime 67}$ Frankl made survival in a concentration camp into a matter of mental health, and Lawrence Langer and Primo Levi have found his approach objectionable.

Timothy Pytell further documents both Frankl's semicollaboration with the Nazis before and during WWII as well as his objectionable reconciliatory interaction with the Austrian Nazis in power following the war (for example, Kurt Waldheim). By accepting important awards from them, he helped legitimize their actions. Thus we have a very controversial figure before us-one who appealed to his American audience because he offered comfort with his claim that the Holocaust was basically a survivable trial and that anger should no longer be directed towards the Nazis. Furthermore, his well-known claim that there is "no collective guilt," that "there were good Nazis and bad Nazis," "good prisoners and bad prisoners" and, most significantly, "good SS and bad SS,"68 helped to legitimize the Holocaust.

67 Timothy Pytell, "The Missing Pieces of the Puzzle: A Reflection on the Odd Career of Viktor Frankl," Journal of Contemporary History 35, no. 2 (April 2000): 300.

68 Speech given on Vienna Rathausplatz on March 10, 1988 on the fiftieth anniversary of "the occupation of Austria by the troops of Hitler's Germany." 
As Pytell remarks, "Frankl was helping in the domestic rehabilitation of Waldheim. That Frankl took the medal from Waldheim in these circumstances (after the Waldheim affair) can only be construed as disgraceful." ${ }^{69}$ However, Pytell also concedes that "this engagement in white-washing of the past was the only possibility in the post-war Austrian culture of denial and arguably Frankl's own choices in the 1930s colored his strategy for coming to terms with the past." ${ }^{70}$ In America, on the other hand, he was a forerunner of the self-help movement and was widely recognized by spiritual psychologists who were seeking a way to reconcile the events of recent history with the existence of God and the possibility of a meaningful life too.

Reuven P. Bulka has, unlike Pytell, a very positive reading of Frankl. He believes that Frankl's logotherapy is a good response to the Holocaust, as it taught the world that positive meaning can be found in any situation. He argues that the Holocaust and Hitler gave the earth saints (like Frankl). ${ }^{71}$ The ultimate question, from my point of view, then, is this: Is horror and misery acceptable if it proves that some individuals are capable of transcendence? Would it be preferable for people to live without the need for such heroism and instead enjoy a harmonious and peaceful world? Would it be better for the "weak" to have a decent life, not just the extremely strong or gifted?

Another, but very different, take on transcending death by transforming the world's consciousness can be found in the work of Simon Wiesenthal (b. 1908 in Buczacz/Buchach, Galicia, then part of Austria-Hungary, now Ternopil Oblast in Ukraine; d. 2005

69 Timothy Pytell, "The Missing Pieces of the Puzzle: A Reflection on the Odd Career of Viktor Frankl," Journal of Contemporary History 35, no. 2 (April 2000), 304.

70 Timothy Pytell, "Viktor Frankl: The Inside Outsider," in Austrian Lives, eds. Günter Bischof, Fritz Plasser, and Eva Maltschnig (New Orleans: University of New Orleans Press, 2012), 247.

71 Reuven P. Bulka, "Logotherapy as a Response to the Holocaust," Tradition: A Journal of Orthodox Jewish Thought 15, nos. 1/2 (SpringSummer 1975): 89-96. 
in Vienna). He lived in Lviv at the outbreak of WWII. Before that, however, he went to school in Vienna and studied at the Technical University in Prague, as Lviv University did not accept him due to his Jewishness. He miraculously survived six concentration campsJanowska, Kraków-Płaszów, Gross-Rosen, Chemnitz, Buchenwald, and Mauthausen-Gusen. After the war, Wiesenthal dedicated his life to tracking down and gathering information on fugitive Nazi war criminals so that they could be brought to trial. Transforming the trauma of being an outcast in a strength, he sought justice for his murdered fellow citizens.

Wiesenthal was first an aide to the American War Crimes Office in Linz, where in 1947 he founded the Jewish Historical Documentation Center. There, he diligently collected information about Nazi criminals from Jewish camp survivors. The center was a one-man operation, which he financed with his own money; he lived very modestly, simply in gratitude for his incredible reunification with his wife and chance to have a regular family life. He even rejected any kind of German restitution payment, as he was not willing to accept German money in the wake of the brutal murder of eighty-nine members of his and his wife's family.

As Wiesenthal's agenda developed and his name became well known, he moved his operation to Vienna where in 1961 he opened the Documentation Center of the Association of Jewish Victims of the Nazi Regime. There, he continued the work of locating escaped Nazi criminals and helping Jews locate their displaced relatives. He was instrumental in high-profile cases, such as exposing the former Nazis in Bruno Kreisky government in 1970 and the Nazi past of the Austrian president and secretary general of the United Nations, Kurt Waldheim, in the 1980s.

This Ukrainian Jew became world famous for his untiring work on behalf of those who had no voice. Wiesenthal became the conscience of the world and deputy for the dead at a time when nobody wanted to hear about the horrors that the Jews suffered and at a time when antisemitism still prevailed in Europe. He only received occasional help from his fellow citizens and the relevant legal institutions often did not trust the information he provided. Even when he provided clear witnesses, they dragged out 
proceedings for years and the courts would dismiss the murderers on technicalities. There was really no hope that real justice could be achieved. Nevertheless, Wiesenthal succeeded in bringing to court some of the criminals who were protected by the new administration in Germany and, even more so, in Austria. These men had been helped by friendly and rich organizations like ODESSA (Organization der SS-Angehörigen), the Catholic Church in Italy, or non-extradition South American regimes. ODESSA, the secret escape organization of the SS underground, was especially effective in helping its members to escape justice. Another of Wiesenthal's achievements was the Austrian "Wiesenthal Law." It ruled that stolen works of art must be returned to their rightful owners.

His book The Murderers Among Us (1967) is a biographical, eye-opening account of some of his activities and experiences, his struggles and connections with the vast number of people who came to him for help. The book, consequently, is also an account of their lives. The stories collected in it are often unbelievable, yet every detail was painstakingly researched and verified. The Murderers Among Us reveals the lives of former inmates and victims of terror, as well as those of many important Nazi criminals-among them, Eichmann, Mengele, Bormann (Hitler's right hand), Stangl (the supervisor of the Hartheim Euthanasia Center and commander of Sobibor and Treblinka, who oversaw the death of about one million people), and Hermine Braunsteiner (the sadist at Majdanek and Ravensbruck).

Wiesenthal helped to locate some of these Nazis, such as Eichmann and Stangl, but he had to resign himself to many escaping for a variety of reasons. With so few witnesses left alive, the courts were obscenely lenient toward Nazi criminals. The struggle Wiesenthal undertook was truly heroic and awakened awe and admiration, not just for his courage and painstaking research, but for his unwavering sense of fairness and justice. He repeatedly overcame hurdles when trying to find Nazis who were protected by powerful institutions.

Wiesenthal shows that Austria was one of the worst nests of Nazism - war criminals could survive there long after the Third Reich was dead. It was the place where the Nazis had schooled themselves 
in technologies of mass murder by killing hundreds of thousands of their own compatriots first. These victims were called "lives not worthy of living." ${ }^{72}$ A Galician himself, Wiesenthal explained why, later, most of the extermination camps were created in Poland and why the Jews of Ukraine suffered the worst. He pointed out that this was because in these countries the Germans were able to count on the help of the local population. These countries had no protective legislation to counteract the extermination law of the Nazis, and the level of antisemitism was disproportionately high compared to other parts of Central, Southern, and Western Europe where Jews were often protected by a sometimes substantial number of their fellow citizens.

The worst crimes were often kept secret from the population of the occupied countries. Not so in Galicia and Poland, where such crimes were often eagerly and sadistically carried out by the local population or with their full knowledge. ${ }^{73}$ SS officers, Wiesenthal reports, were given the Cross of Merit (Kriegsverdienstkreuz) "for psychological discomfort" (für seelische Belastung-code for skill in the technique of mass extermination) due to working in such conditions. ${ }^{74}$

While he was born in one of the most unfortunate parts of the world at a most unfortunate time, Wiesenthal chose to emigrate to a hotbed of Nazis - Austria. It is true, they could not kill him or torture him anymore, but if he had wanted to live a peaceful life he could have gone to one of the English-speaking countries, where sympathy for the Nazis was almost nonexistent and where the legal system was not on the side of the criminals. In Austria, Nazis were able to hide easily and even obtain high administrative positions. They could even disappear without a trace.

The Cold War, which had set in by the 1950s, was also of help to the murderers. As long as they were willing to resist Communism,

72 See introduction to Simon Wiesenthal, The Murderers Among Us (New York: McGraw-Hill Book Company, 1967).

73 Ibid., 271.

$74 \quad$ Ibid., 301. 
Nazis could be incorporated into a country's political structure and even given high posts without any problems. After 1955, they were granted amnesty by various presidential decrees. Pending proceedings were suspended by the courts. Proven criminals were acquitted in Austria. Sometimes they were even applauded in the courtrooms. ${ }^{75}$

The history of Wiesenthal's hunts for Nazis is described in detail in a number of studies (see bibliography), particularly by Daniel Stahl, who confirms Wiesenthal's claims: "tracking down fugitives was not always the main problem in prosecuting Nazi criminals. Years of inactivity among investigative authorities, interpretations of laws that favored perpetrators and continued resistance to the idea of punishing Nazi crimes, greatly hindered efforts to pursue those who had gone underground in South America", 76 "Interpol's strict refusal to get involved in cases involving former Nazis doesn't fit in with the overall picture of the 1960s as a decade of manhunts for prominent fugitives"; 77 "The Eichmann case had revealed how passively state and international institutions had acted and how much more needed to be done in hunting down Nazis." ${ }^{17}$

Wiesenthal's book brings together the individual stories of former camp inmates with his own biography against the backdrop of the politics of the period. It was written in the 1960s, twenty years after the crimes had been committed. The number of survivors was rapidly diminishing and their memories were already becoming less helpful in court. Indeed, until 1961, when the Israelis captured Eichmann in South America and tried him in Jerusalem, it was almost impossible to achieve any success or command any attention in Austria and Germany with regard to the issue. Those countries were simply in denial and were hoping that the past would simply

Ibid., 191.

Daniel Stahl, Hunt for Nazis: South America's Dictatorships and the Prosecution of Nazi Crimes (Amsterdam: Amsterdam University Press, 2018), 125-126.

Ibid., 153.

Ibid., 110. 
disappear or be appeased by a few inane gestures. Wiesenthal was instrumental in making sure this did not happen and, in 1977, the Simon Wiesenthal Center, which continues his work, was created in Los Angeles.

In The Murderers Among Us, Wiesenthal has no truck with collective guilt:

\begin{abstract}
A Jew who believes in God and in his people, does not believe in the principle of collective guilt. Didn't Jews suffer for thousands of years because we were said to be collectively guilty - all of us, including the unborn children - of the crucifixion, the epidemics of the Middle Ages, communism, capitalism, bad wars, bad peace treaties? All ills of mankind, from the pestilence to the atomic bomb, are "the fault of the Jews." We are the eternal scapegoat. We know that we are not collectively guilty, so how can we accuse any other nation, no matter what some of its people have done, of being collectively guilty? ${ }^{79}$
\end{abstract}

The content of Wiesenthal's memoirs is so gripping that its form is practically see-through. Wiesenthal is an excellent narrator and his writing has an existential quality. He definitely transformed his own inner exile into a tireless fight for justice of the highest kind and is one of the best examples of giving life meaning. He sought justice for the dead, who could not thank him. He was resilient enough to perform this task for many decades and having lived a very long life. He succeeded in giving the Jewish dead a voice that could not be ignored and that contributed to the transformation of world awareness.

Wiesenthal has also left a powerful legacy in refusing to propose either resentment as an answer to the Holocaust (as Jean Améry did) or forgiveness of the perpetrators (as Eva Mozes Kor did). His answer is to raise the question of how to think through the Holocaust and leave the answer open. Peter Banki writes: "In what one might identify as a classical philosophical gesture, Wiesenthal interprets the demand for forgiveness of the Nazis and 
their crimes as a question, which is to say, as an identifiable topos that can be situated and discussed as such." $80 \mathrm{He}$ adds: "One can read The Sunflower ${ }^{81}$ as the invention of a powerful resistance machine to the world's demand for closure and normalization." ${ }^{82}$

80 Peter Banki, The Forgiveness to Come: The Holocaust and the Hyper-Ethical (New York: Fordham University Press, 2018), 44.

81 Simon Wiesenthal, The Sunflower: On the Possibilities and Limits of Forgiveness (New York: Schocken Books, 1997).

82 Ibid., 46. 